\title{
Study on Quality of Soluble Dietary Fiber from Jujube (Z. vulgaris Lam) with Different Treatments
}

\author{
Jiawei Shao, Jianxin Fu*, Guixiang Zhang \\ Department of Food Science and Nutrition, University of Jinan, Jinan 250002, China
}

\begin{abstract}
The studies focused on plant soluble dietary fiber. The apparent characteristics of SDF from the Jujube under different treatment methods can provide theoretical support for product development to obtain the best trait products. Optimal extraction conditions, physical properties and antioxidant activity of SDF from the Jujube were investigated. The yield of $20.17 \pm 0.16 \%$ for extraction of soluble dietary fiber from Jujube were obtained as extraction temperature was $94{ }^{\circ} \mathrm{C}$, extraction time was $40 \mathrm{~min}$ and ratio of raw material to water was 1:21. The physical properties of SDF were ascertained by measuring dissolution time, rehydration, swelling ability and bulk density, respectively. And it was evaluated by FT-IR and scanning electronic microscopy (SEM). Furthermore, it was proved that the soluble dietary fiber extracted by vacuum freeze dried had higher scavenging ability than that of vacuum dried and hot dried against DPPH, $\mathrm{ABTS}^{+}$and hydroxyl radical. It has good antioxidant function and can slow down intestinal aging as a basis for new food development.
\end{abstract}

\section{Introduction}

Jujube is the fruit of the Zihamus jujube Mill of the Rhamnaceae [1-2]. Traditionally, it is regarded as a medicine to reduce blood sugar and blood pressure, or an edible to enhance human immunity [3-4] due to its rich in abundant vitamins [5], minerals and trace elements [6]. Dietary fiber mainly presents in the cell wall of plants including cellulose [7], hemicellulose [8], resin, pectin and lignin. It included soluble dietary fiber (SDF) and insoluble dietary fiber, (IDF) depending on the solubility of the dietary fiber [9].

Recent research pointed SDF has positive effect on human physiology including laxative [10] and hypolipidemic [11]. However, the chemical organic constituents of jujube were limited to the researches on the determination of nutrient components and total flavonoids. There were few researches on the extraction process and antioxidant activity of SDF. Therefore, this work mainly focused on exploring the optimal condition to extract SDF from jujube in order to increase the yield, as well as the antioxidant and physical properties of jujube.

\section{Materials and methods}

\subsection{Materials}

Jujube was harvested in October 2018 from Jinan (Long. $117^{\circ} 00^{\prime} \mathrm{E}$; Lat. $36^{\circ} 40^{\prime} \mathrm{N}$ ) of Shandong province in China. The fruits were identified as Z .vulgaris Lam by researcher $X$. Zhang (Department of Life Sciences, Shandong
Normal University). The whole jujube were washed with water and freezed rapidly at $-37^{\circ} \mathrm{C}$ with liquid nitrogen after denucleation. Finally, dried fruits were crushed by superfine grinding at 200 order to be used. The following regents contained 1,1-diphenyl-2-picrylhydrazyl (DPPH) and diammonium salt (ABTS) were purchased from Sigma Chemical Co. (St. Louis, MO, USA).

\subsection{Process of extraction of SDF}

As shown in Fig. 1, Jujube pulp was immersed three times with petroleum ether (boiling ranged from $30{ }^{\circ} \mathrm{C}-60{ }^{\circ} \mathrm{C}$ ) and $70 \%(\mathrm{~V} / \mathrm{V})$ ethanol for $24 \mathrm{~h}$ at room temperature of $27{ }^{\circ} \mathrm{C}$ in order to remove oily ingredients and pigments [12]. The rest of residue was used to extract SDF by hot water with different extraction temperature, extraction time and ratio of raw material to water. The resulting solution was treated with papain $(\mathrm{pH} 6.6,8000 \mathrm{u} / 100 \mathrm{~mL})$ at $55{ }^{\circ} \mathrm{C}$ for $4 \mathrm{~h}$ and then filtered to remove the protein [13]. Subsequently, the saccharification enzyme (500 $\mathrm{u} / 100 \mathrm{~mL}$ ) was added and reacted at $60{ }^{\circ} \mathrm{C}$ for $2 \mathrm{~h}$ after it was extinguished at $80^{\circ} \mathrm{C}$ with $\mathrm{pH} 4.2$ of PBS $(0.1 \mathrm{~mol} / \mathrm{L})$ [14]. After filtration, the supernatant was precipitated with four volumes of absolute ethanol, and the precipitate was collected by centrifugation at $9500 \mathrm{rpm}$ for $25 \mathrm{~min}$ [15]. Finally, it was washed with diethyl ether, absolute ethanol and acetone via different dried methods to obtain SDF.

\footnotetext{
* Corresponding author: fujx93@163.com
} 


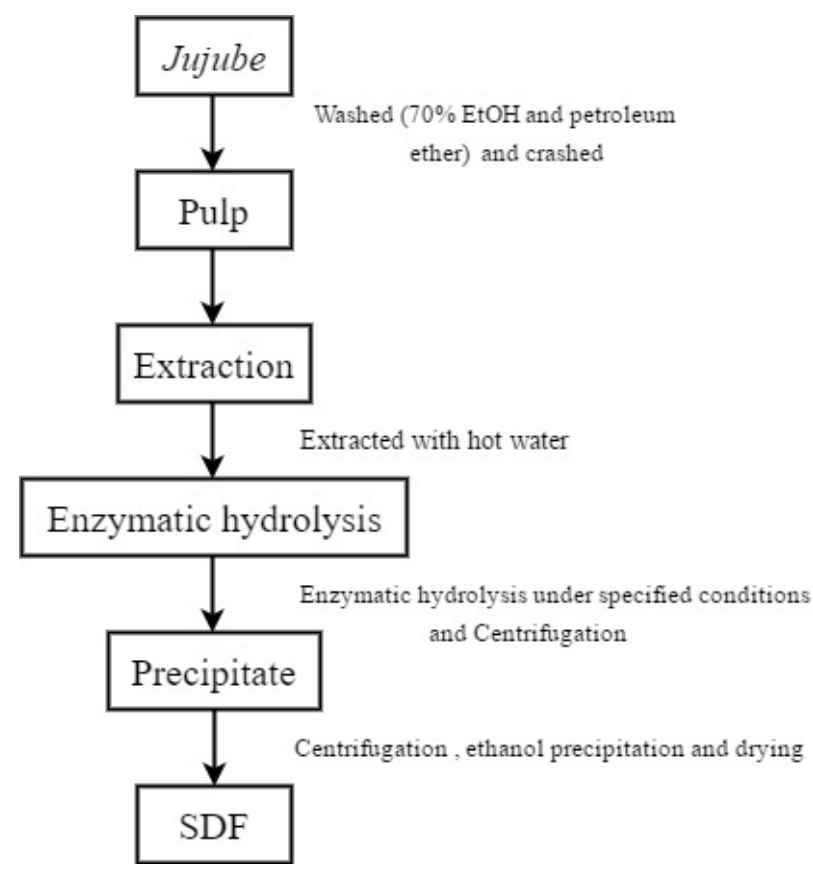

Fig. 1. Scheme for SDF extraction of Jujube.

\subsection{Experimental design of response surface methodology}

The influences on the extraction process including extraction time (A:10 $\mathrm{min}, 20 \mathrm{~min}, 30 \mathrm{~min}, 40 \mathrm{~min}, 50$ min and $60 \mathrm{~min}$ ), extraction temperature $\left(\mathrm{B}: 50^{\circ} \mathrm{C}, 60^{\circ} \mathrm{C}\right.$, $70{ }^{\circ} \mathrm{C}, 80^{\circ} \mathrm{C}, 90^{\circ} \mathrm{C}$ and $\left.100{ }^{\circ} \mathrm{C}\right)$ and ratio of raw material to water $(\mathrm{C}: 1: 5 \mathrm{~g} / \mathrm{mL}, 1: 10 \mathrm{~g} / \mathrm{mL}, 1: 15 \mathrm{~g} / \mathrm{mL}, 1: 20 \mathrm{~g} / \mathrm{mL}$, $1: 25 \mathrm{~g} / \mathrm{mL}$ and $1: 30 \mathrm{~g} / \mathrm{mL}$ ) were investigated. Besides, to find the best combination, the yield of SDF under these extraction factors was recorded via the Box-Behnken experimental design (BBD) with 17 experiments in order (Table 1).

\subsection{Different treatments of SDF}

The SDF was processed with three treatments including vacuum freeze dried (noted as T-1), hot dried (noted as T2 ) and vacuum dried (noted as T-3). For T-1, the extracted wet SDF was frozen at $-25{ }^{\circ} \mathrm{C}$ for $20 \pm 2 \mathrm{~h}$ [16] in the refrigerator in advance. The actual experiments included 2 stage: the first stage was under the conditions with the temperature of $-65^{\circ} \mathrm{C}$ and pressure of $20 \mathrm{~Pa}$ for $20 \mathrm{~h}$; the second stage was prepared at the temperature of $-55^{\circ} \mathrm{C}$ and pressure of $15 \mathrm{~Pa}$ for $15 \mathrm{~h}$ [17]. In terms of $\mathrm{T}-2$, the wet SDF was kept in the oven at temperature of $85^{\circ} \mathrm{C}$ with $2.5 \mathrm{~m} / \mathrm{s}$ for $20 \mathrm{~h} \mathrm{[18]} \mathrm{to} \mathrm{be} \mathrm{dried.} \mathrm{Besides,} \mathrm{the} \mathrm{wet}$ SDF was spread on a tray and dried at vacuum environment with $20 \mathrm{~Pa}$ at room temperature of $27^{\circ} \mathrm{C}$ for the $\mathrm{T}-3$ treatment.

\subsection{Antioxidant capacity}

The method of DPPH radical scavenging of SDF from Jujube was experienced via the reported essay [19]. $5 \mathrm{~mL}$ of prepared DPPH solution $(0.1 \mathrm{mM}$ in ethanol) was mixed with different concentrations of SDF samples. Then, the mixture reacted for $45 \mathrm{~min}$ in the dark at $27^{\circ} \mathrm{C}$ [20] and detected at $517 \mathrm{~nm}$ [21] via UV-vis (UV2501PC). The experiment was conducted with ascorbic acid as the control.

DPPH $(\%)=(1-$ Abssample $/$ Abscontrol $) \times 100$

The $\mathrm{ABTS}^{+}$radical scavenging ability test was mentioned by earlier report [22]. Different concentrations of SDF solutions ( $1 \mathrm{~mL}$ with $\mathrm{pH} 7.1$ ) were added into the solution [23], which was a mixture of phosphate buffer (2.5 mL at $0.2 \mathrm{M}$ with $\mathrm{pH} 6.6$ ) and potassium ferricyanide solution $(2.5 \mathrm{~mL}$ at $1 \%(\mathrm{~m} / \mathrm{v}))$. In order to reacted completely, all of the samples were protected at $50{ }^{\circ} \mathrm{C}$ under water bath for $40 \mathrm{~min}$ in dark room [24]. Then, the $\mathrm{ABTS}^{+}$radical solution was added into trichloroacetic acid solution $(2.5 \mathrm{~mL}$ at $0.5 \mathrm{M})$ to get the steady absorbance at $700 \mathrm{~nm}$. The $\mathrm{ABTS}^{+}$radical scavenging ability was tested at around $700 \mathrm{~nm}$ with the blend of 2.5 $\mathrm{mL}$ distilled water and ferric chloride solution $(0.5 \mathrm{~mL}$ at $0.05 \mathrm{mM}$ ) at $20 \mathrm{~min}$ after the initial mixing. The solution without any samples was used as control.

Percent Inhibitation $(\%)=(1-$ Abssample/Abscontrol $)$ $\times 100$

In this study, $\mathrm{OH}^{-}$scavenging ability was estimated according to the method [25]. The reaction blend contained $\mathrm{FeSO}_{4} \cdot 7 \mathrm{H}_{2} \mathrm{O}$ solution $(2 \mathrm{~mL}$ at $6 \mathrm{mM})$, salicylic acid-ethanol solution ( $2 \mathrm{~mL}$ at $7.5 \mathrm{mM}$ with $\mathrm{pH}$ 6.7), $\mathrm{H}_{2} \mathrm{O}_{2}$ $(2 \mathrm{~mL}$ at $8 \mathrm{mM})$ and different concentrations of SDF solution $(2 \mathrm{~mL})$ [26]. Then, the blend reacted for $30 \mathrm{~min}$ at $37{ }^{\circ} \mathrm{C}$ and measured at $510 \mathrm{~nm}$ via UV-vis. This was ordered with ascorbic acid as the control.

Scavenging percent $(\%)=\left[1-\left(\mathrm{A}-\mathrm{A}_{0}\right) / \mathrm{A}_{1}\right] \times 100$

$\mathrm{A}=$ Absorbance of extract sample; $\mathrm{A}_{0}=$ Absorbance of control (to replace sample with water); $A_{1}=$ Absorbance of blank (to replace sample and $\mathrm{H}_{2} \mathrm{O}_{2}$ solution with water). The SDF was processed with three treatments including vacuum freeze dried

\subsection{Physical and chemical properties}

\subsubsection{FT-IR spectroscopy}

The infrared (IR) spectra of SDF was performed by the fourier transform infrared spectrophotometer (Thermo Electron Corp., Waltham, MA, USA). The SDF mixture (with $5 \mathrm{mg}$ sample and $100 \mathrm{mg} \mathrm{KBr}$ ) was determined from $4000 \sim 400 \mathrm{~cm}^{-1}$ (mid infrared region) to analyze the characteristic groups [27].

Table 1 Design-expert design scheme and experimental results

$\begin{array}{cc}\text { Experiments } & \begin{array}{c}\text { A:Extraction } \\ \text { time(min) }\end{array}\end{array}$

B:Exaction
temperature $\left({ }^{\circ} \mathrm{C}\right)$

C:Ratio of raw
material to water

Actual yield (\%)
Predict value (\%) 


\begin{tabular}{cccccc}
\hline 1 & $-1(30)$ & $-1(80)$ & $0(1: 20)$ & $17.15 \pm 0.13$ & 16.97 \\
2 & $1(50)$ & $-1(80)$ & $0(1: 20)$ & $18.34 \pm 0.23$ & 18.37 \\
3 & $-1(30)$ & $1(100)$ & $0(1: 20)$ & $18.30 \pm 0.16$ & 18.27 \\
4 & $1(50)$ & $1(100)$ & $0(1: 20)$ & $19.56 \pm 0.33$ & 19.48 \\
5 & $-1(30)$ & $0(90)$ & $-1(1: 15)$ & $17.79 \pm 0.21$ & 17.90 \\
6 & $1(50)$ & $0(90)$ & $-1(1: 15)$ & $19.89 \pm 0.16$ & 19.84 \\
7 & $-1(30)$ & $0(90)$ & $1(1: 25)$ & $18.69 \pm 0.19$ & 18.79 \\
8 & $1(50)$ & $0(90)$ & $1(1: 25)$ & $19.87 \pm 0.21$ & 19.76 \\
9 & $0(40)$ & $-1(80)$ & $-1(1: 15)$ & $17.81 \pm 0.18$ & 17.88 \\
10 & $0(40)$ & $1(100)$ & $-1(1: 15)$ & $19.56 \pm 0.10$ & 19.48 \\
11 & $0(40)$ & $-1(80)$ & $1(1: 25)$ & $18.50 \pm 0.11$ & 18.50 \\
12 & $0(40)$ & $1(100)$ & $1(1: 25)$ & $19.70 \pm 0.19$ & 19.63 \\
13 & $0(40)$ & $0(90)$ & $0(1: 20)$ & $19.72 \pm 0.16$ & 19.84 \\
14 & $0(40)$ & $0(90)$ & $0(1: 20)$ & $19.71 \pm 0.17$ & 19.84 \\
15 & $0(40)$ & $0(90)$ & $0(1: 20)$ & $19.89 \pm 0.21$ & 19.79 \\
16 & $0(40)$ & $0(90)$ & $0(1: 20)$ & $19.88 \pm 0.22$ & 19.84 \\
17 & $0(40)$ & $0(90)$ & $0(1: 20)$ & $19.99 \pm 0.14$ & 19.84 \\
\hline
\end{tabular}

Table 2 The analysis of variance (ANOVA) of the regression model for the yield response

\begin{tabular}{ccccc}
\hline Variable & SS & DF & F-value & P-value \\
\hline Model & 13.52 & 9 & 56.41 & $<0.0001^{\mathrm{a}}$ \\
$\mathrm{A}$ & 4.10 & 1 & 154.16 & $<0.0001^{\mathrm{a}}$ \\
$\mathrm{B}$ & 3.54 & 1 & 132.89 & $<0.0001^{\mathrm{a}}$ \\
$\mathrm{C}$ & 0.37 & 1 & 13.73 & $0.0076 \mathrm{~b}$ \\
$\mathrm{AB}$ & 0.24 & 1 & 0.046 & 0.8363 \\
$\mathrm{AC}$ & 0.21 & 1 & 7.95 & 0.0258 \\
$\mathrm{BC}$ & 0.076 & 1 & 2.84 & 0.1358 \\
$\mathrm{~A}^{2}$ & 1.87 & 1 & 70.26 & $<0.0001^{\mathrm{a}}$ \\
$\mathrm{B}^{2}$ & 2.93 & 1 & 110.01 & $<0.0001^{\mathrm{a}}$ \\
$\mathrm{C}^{2}$ & 0.052 & 1 & 1.97 & 0.2036 \\
Residual & 0.19 & 7 & & 0.1609 \\
Lack of Fit & 0.13 & 3 & 2.96 & \\
Pure Error & 0.058 & 4 & & \\
Cor Total & 13.70 & 16 & & \\
C.V.\% & 0.86 & & & \\
\hline
\end{tabular}

${ }^{\mathrm{a}}$ Significant at 0.001 level. ${ }^{\mathrm{b}}$ Significant at 0.01 level.

Table 3 The chemical composition of SDF with different treatments

\begin{tabular}{cccc}
\hline Items & T-1 & T-3 & T-2 \\
\hline Protein (\%) & $0.16 \pm 0.06^{\mathrm{b}}$ & $0.22 \pm 0.12^{\mathrm{a}} \pm 0.36^{\mathrm{b}}$ \\
Carbohydrate (\%) & $51.61 \pm 2.02^{\mathrm{a}}$ & $82.56 \pm 2.71^{\mathrm{b}}$ & $74.32 \pm 2.21^{\mathrm{c}}$ \\
Total flavonoid & $0.16 \pm 0.03^{\mathrm{b}}$ & $0.14 \pm 0.06^{\mathrm{c}}$ & $0.13 \pm 0.05^{\mathrm{a}}$ \\
(mg GAE/100 mg) & & & $11.25 \pm 1.24^{\mathrm{c}}$ \\
Uronic acid (\%) & $7.15 \pm 0.15^{\mathrm{a}}$ & $12.39 \pm 1.68^{\mathrm{b}}$ & \\
\hline
\end{tabular}

the different lowercases indicated significant difference $\left(\mathrm{P}_{\mathrm{b}}<0.05\right)$ in the same line.

Table 4Physical properties of SDF under the T-1, T-2, T-3 treatments. *

\begin{tabular}{ccccc}
\hline & $\begin{array}{c}\text { Dissolution time } \\
(\mathrm{s})\end{array}$ & $\begin{array}{c}\text { bulk density } \\
(\mathrm{g} / \mathrm{mL})\end{array}$ & swelling ability $(\mathrm{mL} / \mathrm{g})$ & Rehydration \\
\hline $\mathrm{T}-1$ & $0.210 \pm 0.020^{\mathrm{b}}$ & $7.067 \pm 0.145^{\mathrm{a}}$ & $32.000 \pm 3.000^{\mathrm{c}}$ & $0.480 \pm 0.036^{\mathrm{a}}$ \\
$\mathrm{T}-2$ & $0.320 \pm 0.027^{\mathrm{a}}$ & $3.667 \pm 0.208^{\mathrm{b}}$ & $80.667 \pm 3.056^{\mathrm{a}}$ & $0.410 \pm 0.036^{\mathrm{b}}$ \\
$\mathrm{T}-3$ & $0.227 \pm 0.021^{\mathrm{b}}$ & $3.937 \pm 0.208^{\mathrm{b}}$ & $52.337 \pm 3.786^{\mathrm{b}}$ & $0.397 \pm 0.021^{\mathrm{b}}$ \\
\hline
\end{tabular}

*Result were present as means \pm standard deviation $(n=3)$. Means with different uppercase letter superscripts in the same column were significant different at $\mathrm{P}<0.05$. 


\subsubsection{Scanning Electronic Microscopy of SDF}

The scanning electronic microscopy of SDF has been reported by the scanning projection electron microscope (Thermo Prisma E., Waltham, MA, USA). A small amount of the SDF sample was detected after it was dried by an infrared lamp for $10 \mathrm{~min}$ [28-29].

\subsubsection{Determination of dissolution time}

To maintain $50 \mathrm{~mL}$ mixture ( $2 \mathrm{~g}$ sample with $50 \mathrm{~mL}$ water $)$ under $23 \pm 2{ }^{\circ} \mathrm{C}$ until it was completely dissolved. The dissolution time was noted as Tsp. No precipitation was formed when standing for 30 seconds after the complete dissolution can be regarded as completely dissolution determination [30].

\subsubsection{Determination of bulk density}

The SDF was scattered through a funnel in a $5 \mathrm{~mL}$ graduated cylinder. Quality was recorded as $\mathrm{m}_{0}$ when the mass was at a volume of $5 \mathrm{~mL}$.

$\rho=m_{0} / 5$

$m_{0}=$ the mass of SDF scattered $5 \mathrm{~mL}, \mathrm{~g} ; \rho=$ the bulk density, $\mathrm{g} / \mathrm{mL}$.

\subsubsection{Determination of swelling ability}

SDF was spread into the bottom of scaled tube with water to be fully dissolved (at $27^{\circ} \mathrm{C}$ for $48 \pm 2 \mathrm{~h}$ ). The ratio of difference volume of the sample after and before water absorption to sample mass can be used to estimate the swelling ability.

$$
P=\left(V-V_{0}\right) / m
$$

$V=$ volume after water absorption, $\mathrm{mL} ; V_{0}=$ unabsorbed dry weight volume, $\mathrm{mL} ; m=$ sample quality, $\mathrm{g} ; P=$ the swelling ability, $\mathrm{mL} / \mathrm{g}$.

\subsubsection{Determination of rehydration}

The sample was centrifuged at $4{ }^{\circ} \mathrm{C}$ with $11000 \mathrm{r} / \mathrm{min}$ for $25 \mathrm{~min}$. The water on sample surface was washed with a small amount of absolute ethanol. The ratio of wet to dried weight was the index of rehydration[30].

$R=m / m_{0}$

$R=$ rehydration ratio; $m=$ mass after washing, $\mathrm{mg}$; $m_{0}=$ mass of dry sample, $\mathrm{mg}$.

\subsubsection{Formatting the title}

$0.1 \mathrm{~g}$ of the sample was dissolved in $40 \mathrm{ml}$ ethanol and agitated well to be measured (Beckman CoulterLS 13320, MA, USA).

\subsection{Statistical analysis}

The BBD design and data analysis of RSM was performed using Software Design-Expert (V8.0.6). The significance of diversities was assessed by one-way ANOVA analysis (with the significance of 2 levels). All tests were repeated for three groups, with three parallel tests of each group $(n=3 \times 3)$. Data of triplicate parallel experiences were reported as means \pm standard deviations by Microsoft Office (15.0).

\section{Results and discussion}

\subsection{Extraction factor analysis}

According to Fig. 2 (C), the extraction yield of SDF increased significant $(\mathrm{P}<0.05)$ with the increasing ratio of material to water, and the maximum value is consistent remained at $18.7 \pm 0.84 \%$ when it was $1: 20 \mathrm{~g} / \mathrm{mL}$. It might be dissolved more completely with the action of dilution when the ratio of material to water was lower [31]. On the contrary, higher ratio would increase the specific heat capacity of the system [32], which may increase the destruction of the SDF.

To explore the influence of extraction temperature on yield of SDF, the extraction temperature conditions of $50{ }^{\circ} \mathrm{C}, 60{ }^{\circ} \mathrm{C}, 70{ }^{\circ} \mathrm{C}, 80^{\circ} \mathrm{C}, 90^{\circ} \mathrm{C}$, and $100^{\circ} \mathrm{C}$ was studied, just as shown in the Fig. 2 (B). In the certain temperature range from $50{ }^{\circ} \mathrm{C}$ to $100{ }^{\circ} \mathrm{C}$, the total extraction yield of SDF reached a maximum $(\mathrm{P}<0.05)$ of $18.9 \pm 0.52 \%$ when the extraction temperature reached $90^{\circ} \mathrm{C}$. This situation might be due to the high temperature causing decomposition of SDF [33].

In this part, it can be seen from Fig. 2 (A) that the extraction yield of SDF increased significant $(\mathrm{P}<0.05)$ with the increase of extraction time from $10 \mathrm{~min}$ to $40 \mathrm{~min}$. Longer extension time did not change the extraction rate of the SDF after $40 \mathrm{~min}$, which may be because its fully solubility in the solvent reach at $19.29 \pm 0.35 \%$.

\subsection{Statistical analysis and model fitting}

The relationship between extraction yield of SDF and potential covariates including extraction temperature, extraction time, ratio of raw material to water were measured using the following second order regression equation: $\quad \mathrm{Y}=19.84+0.72 \mathrm{~A}+0.67 \mathrm{~B}+0.21 \mathrm{C}+0.017 \mathrm{AB}-$ $0.23 \mathrm{AC}-0.14 \mathrm{BC}-0.67 \mathrm{~A}^{2}-0.83 \mathrm{~B}^{2}-0.11 \mathrm{C}^{2}$.

According to the Table 2 analysis, the regression model $(\mathrm{P}<0.001)$ and missing term $(\mathrm{P}>0.1)$ indicated that the data fitted the regression model well, and the experimental error was low [34]. Thus, it can be used to predict the extraction yield of SDF in jujube under given extraction conditions.

In this model, extraction time $(\mathrm{A}, \mathrm{P}<0.05)$, extraction temperature $(\mathrm{B}, \mathrm{P}<0.05)$, ratio of raw material to water $(\mathrm{C}$, $\mathrm{P}<0.05)$, the extraction temperature quadratic term $\left(\mathrm{A}^{2}\right.$, $\mathrm{P}<0.05)$ and the extraction time quadratic term $\left(\mathrm{B}^{2}\right.$, $\mathrm{P}<0.05)$ have a significant effect on extraction yield of SDF. The conditions of parameters which was optimized after combined with practical experimental feasibility was 
extraction time of $45 \mathrm{~min}$, extraction temperature at $94^{\circ} \mathrm{C}$ and ratio of raw material to water with 1:21 $(\mathrm{g} / \mathrm{mL})$. The
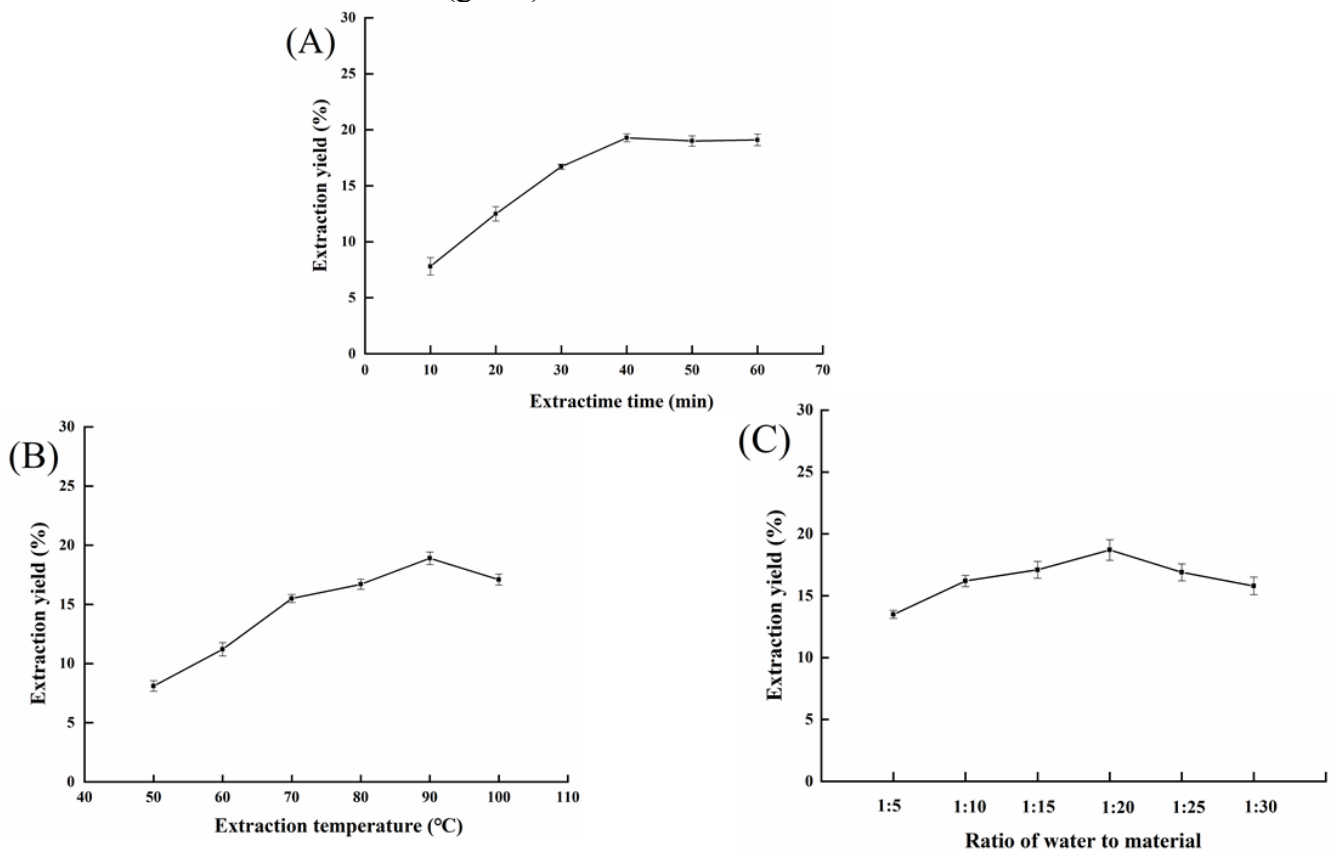

Fig. 2. Effect of extraction time (A), extraction temperature $\left({ }^{\circ} \mathrm{C}\right)(\mathrm{B})$ and ratio of raw material to water $(\mathrm{g} / \mathrm{mL})(\mathrm{C})$ on the extraction yield of SDF.
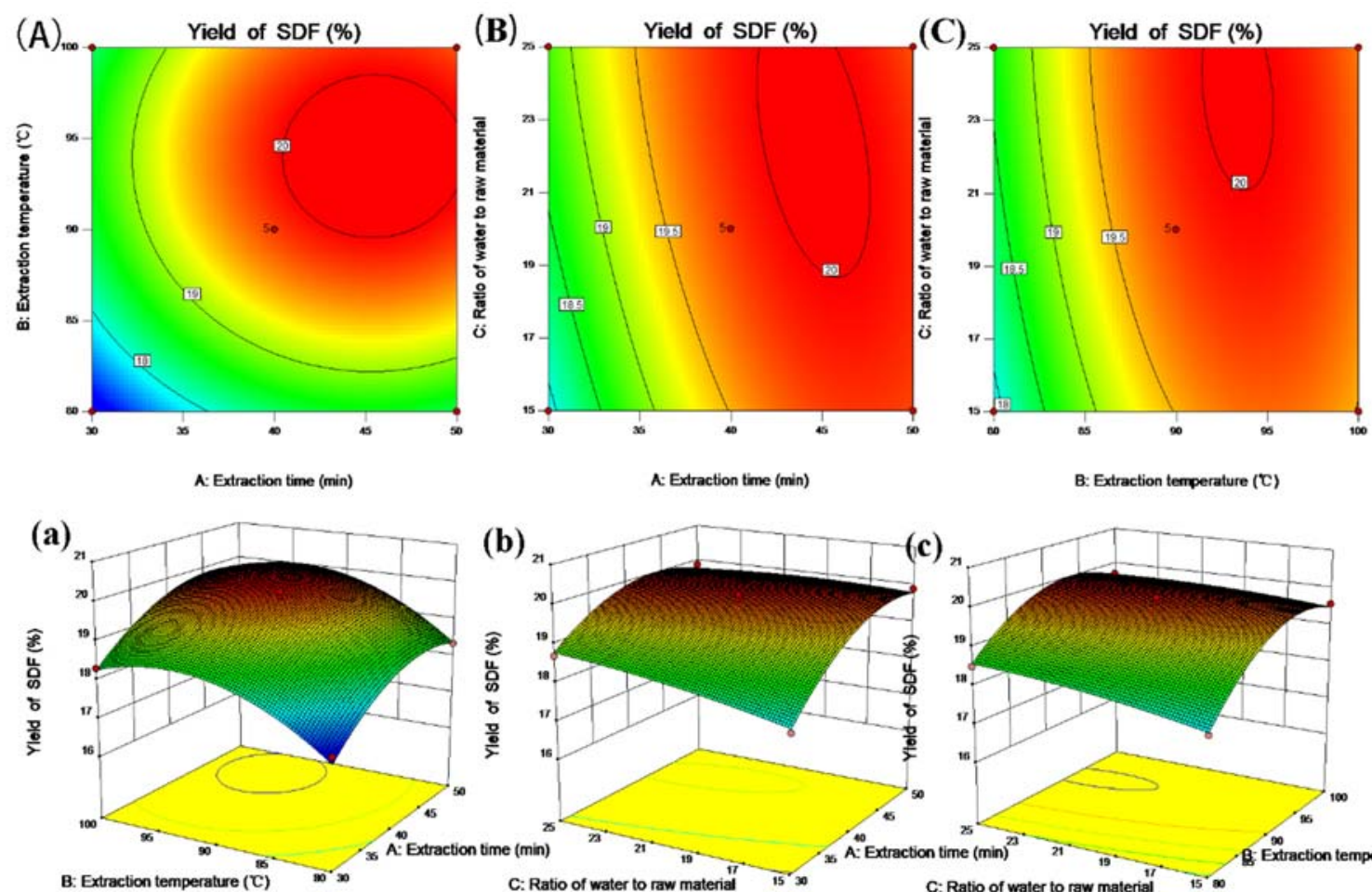

(b)

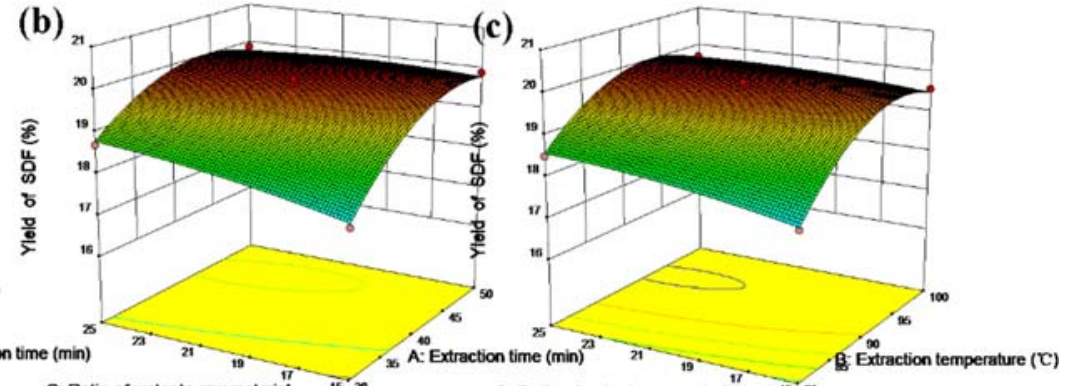

A. Extraction time (min)

B: Extraction temperature ( $(C)$

Fig. 3. Response surface plots of the interaction of various factors on the yield of SDF. (A) and (a) : The factors of time and temperature. (B) and (b) : The factors of time and ratio of raw material to water. (C) and (c) : The factors of temperature and ratio of raw material to water.

extraction yield of SDF under this condition remained $20.17 \pm 0.16 \%$.

\subsection{Analysis of response surface}

The influence of the interaction between the reaction factors with the extraction yield of SDF can be realized by the steepness of the vertical surface of the response 
surface. As shown in Fig. 3, the order of the influence between each factor on extraction yield of SDF was extraction time $>$ extraction temperature $>$ ratio of raw material to water according to the steepness degree from high to low. The shape of contour difference between extraction time and extraction temperature tends to be elliptical, which indicated that the interaction between the quadratic term of these was significant $(\mathrm{P}<0.05)$.

\subsection{Chemical composition results}

The contents of carbohydrates, proteins, uronic acids and total flavonoids in SDF with different treatments were summarized in Table 3 . The results indicated that the higher content of these SDF was carbohydrate, which were $51.61 \pm 2.02 \%, 82.56 \pm 2.71 \%$ and $74.32 \pm 2.21 \%$, respectively. The T-1 contained lower uronic acid content $(7.15 \pm 0.15 \%)$ while it was absent of protein $(0.16 \pm 0.06 \%)$. The phenomenon of this difference in composition indicated that the enzyme produced good deproteinization effect. Thus, SDF can be considered a relatively pure substance. In addition, the deficient of flavonoids and protein detection determined the independence of the antioxidants of the SDF.

\subsection{Physical characterization}

\subsubsection{FT-IR spectrum analysis}

The IR analysis spectrum of the soluble dietary fiber was shown in Fig. 4. The absorption peaks around 1680 to $1639 \mathrm{~cm}^{-1}$ belonged to the $-\mathrm{C}=\mathrm{O}$ carboxy symmetric stretching vibration of the uronic acid groups [34]. The groups of -C-O on the soluble dietary fiber were indicated by the absorption band at 1137 and $1139 \mathrm{~cm}^{-1}$ [35]. The adsorption band at $1072 \mathrm{~cm}^{-1}$ was attributed to the C-O-C stretching vibration [36] of the pyranose pentacyclic ring. It showed that this long chain cellulose with strengthen O$\mathrm{H}$ and short $-\mathrm{CH}_{2}$ absorption peak contained a glycosidicbonded pyranose ring.

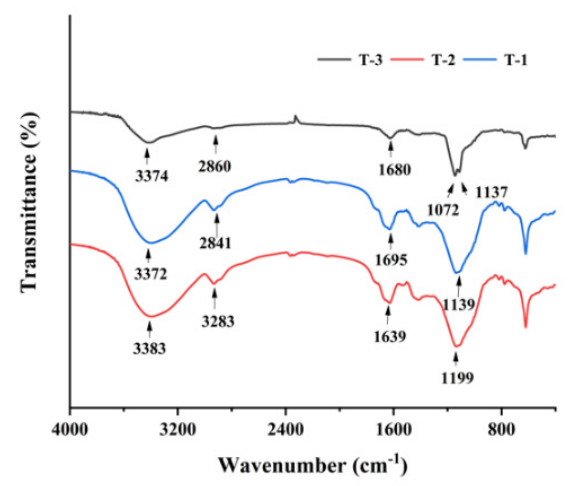

Fig. 4. FT-IR spectra of SDF.

\subsubsection{SEM shape}

There were a large number of obvious pore structures on the surface under the $\mathrm{T}-1$ treatment mode, while the surface of the T-2 was relatively gentle at the same magnification in Fig. 5. The reason for these phenomena could be that the water of SDF slowly evaporated under the action of high temperature, which caused the structure collapsed [37-38] and compacted into an inseparable structure [39]. In addition, the moisture removal efficiency of different drying methods was also an important factor [40] in the coarse pore structure of the SDF surface.
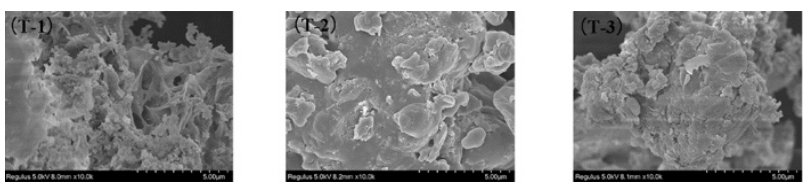

Fig. 5. SEM of SDF with different treatments.

\subsection{Antioxidant capacity analysis}

The principle of DPPH free radical scavenging activity depended on the reports [41-42]. As shown in Fig. 6 (A), it can be seen that the T-1, T-2 and T-3 show a significant $(\mathrm{P}<0.05)$ dose-dependent effect on better free radical scavenging ability in the concentration range from 0.2 $\mathrm{mg} / \mathrm{mL}$ to $4.0 \mathrm{mg} / \mathrm{mL}$. Comparing these three treatments, it can be found that $\mathrm{T}-1$ and $\mathrm{T}-3$ had better oxidation resistance than $\mathrm{T}-2$, which may attribute to that the higher temperature environment destroyed the internal structure of SDF, resulting in a decrease in electron binding ability to DPPH radicals [43]. High temperature treatment also promoted the decomposition of some functional components in SDF (such as polysaccharides and brass) [44] to reduce their hydrogen reduction ability.

The absorbance of ABTS can be determined at $734 \mathrm{~nm}$ to calculate the total antioxidant capacity of the samples [45]. As shown in Fig. 6 (B), the $\mathrm{ABTS}^{+}$radical scavenging activity of $\mathrm{T}-1, \mathrm{~T}-2$ and $\mathrm{T}-3$ were positively correlated $(\mathrm{P}<0.05)$ with the sample concentration range. The scavenging activities were in turn of $\mathrm{T}-1>\mathrm{T}-3>\mathrm{T}-2$. These data demonstrated that the $\mathrm{ABTS}^{+}$free radical scavenging activity of SDF obtained by different drying methods depended on their structural integrity and molecular size [46], which was no different from previous reports.

Gene transcriptional expression process was blocked when the hydroxyl group rapidly reacted with intracellular DNA across the biofilm system [47]. As shown in the Fig. $6(\mathrm{C})$, it could be seen that the hydroxyl radical scavenging activity of $\mathrm{T}-1, \mathrm{~T}-2$ and $\mathrm{T}-3$ were concentration dependent, and it followed the order of $\mathrm{T}$ $1>\mathrm{T}-3>\mathrm{T}-2$. The factor for this phenomenon may be explained by that $\mathrm{T}-1$ provided a amount of active hydroxyl groups such as polysaccharides under the low temperature, which was consistent with previous reports [48].

\subsection{Physical property analysis}

Dissolution time was an important indicator to measure the shrinkage, porosity and cell damage of products, which can be directly present the rehydration rate of the dried SDF in this test [49]. As shown in Table 4, the 
minimum dissolution time of SDF under vacuum freeze dried was $32 \mathrm{~s}(\mathrm{P}<0.05)$.
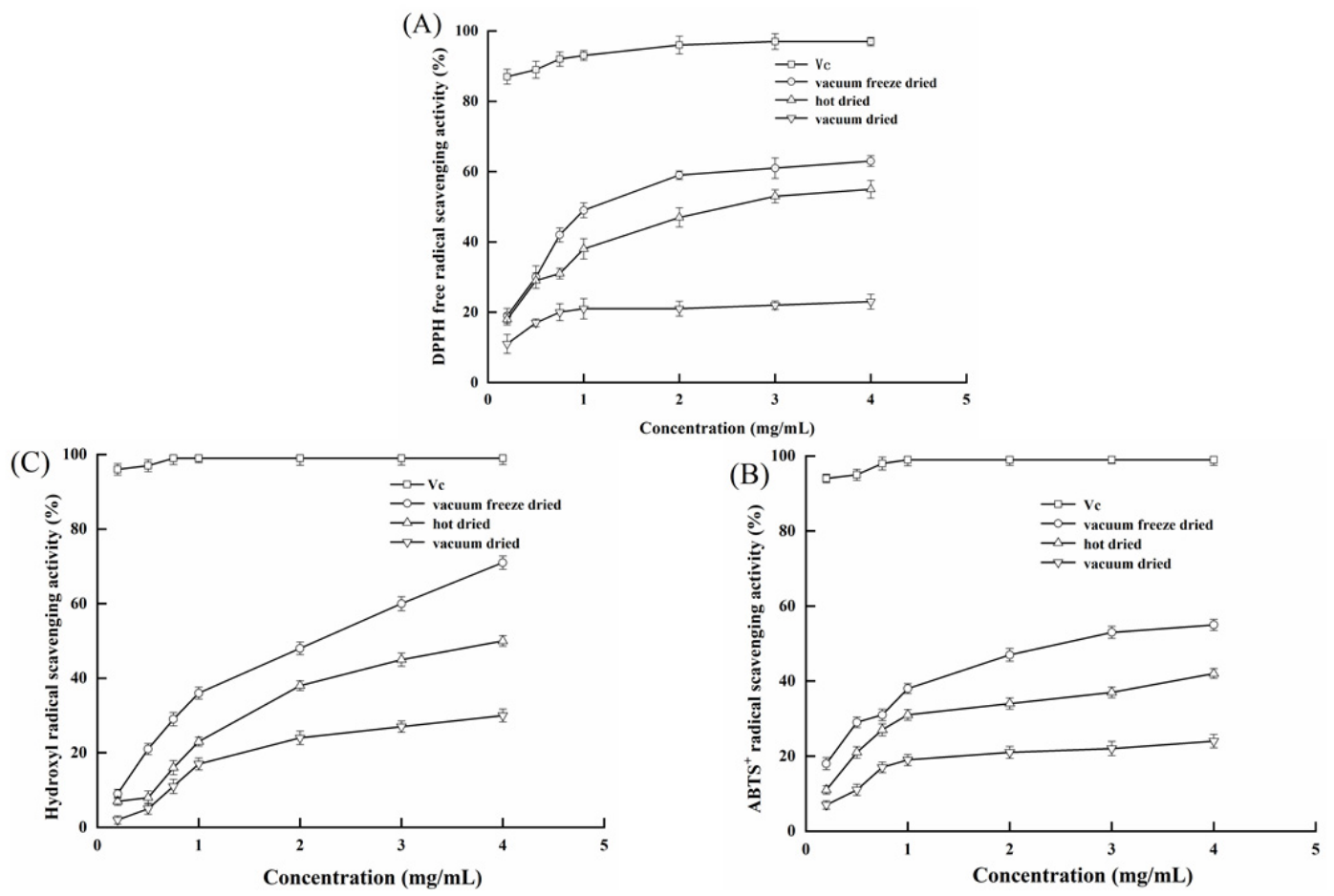

Fig. 6. Antioxidant activities on DPPH free radical scavenging activity (A), ABTS ${ }^{+}$radical scavenging activity (B) and Hydroxyl radical scavenging activity $(C)$ of $\mathrm{SDF}$. Values were present as means \pm SD.

(T-1)

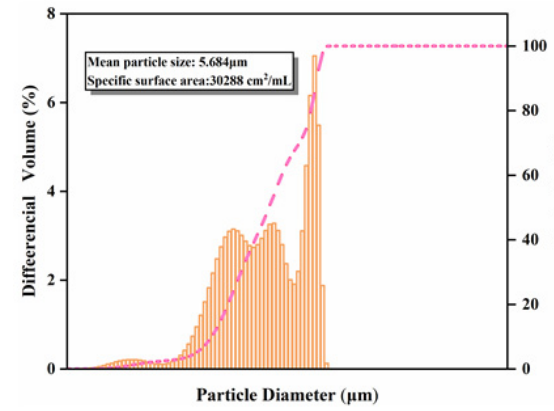

Particle Diameter $(\mu \mathrm{m})$

(T-2)

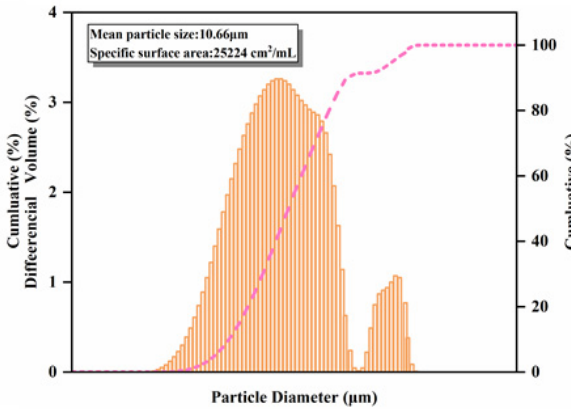

Fig. 7. FT-IR spectra of SDF.

It can be found that the dissolution time under hot dried was significantly longer than vacuum freeze dried ( $\mathrm{T}-1)$ and vacuum dried $(\mathrm{T}-3)(\mathrm{P}<0.05)$. The bulk density was one of the most important parameters reflecting the texture of the powder [50]. The bulk density of SDF was significantly higher $(\mathrm{P}<0.05)$ than vacuum dried $(\mathrm{T}-2)$ and vacuum dried $(\mathrm{T}-3)$ by vacuum freeze dried $(\mathrm{T}-1)$ according to Table 4 . That maybe contribute to that the average particle size of SDF became smaller by the method of hot dried (T-2), when the volume became smaller under the same mass. It maintained the original loose porous structure of the tissue by methods of vacuum dried (T-1) and vacuum freeze dried (T-3), which adopted vacuum freeze sublimation dehydration technology. It was significant difference $(\mathrm{P}<0.05)$ on the swelling ability with these three methods. The order of swelling ability was given in the table as follows: vacuum dried $>$ hot dried >vacuum dried. This may be due to that the molecule structure (especially high molecular polymers such as starch) was destroyed and connected with particles, which eventually leaded to a lower swelling capacity under the high temperature during hot dried. The relative increase in the action of water and gelation leaded to high swelling ability under the treatment of vacuum freeze dried [51]. The effect of different treatments on rehydration of SDF were significant $(\mathrm{P}<0.05)$. This phenomenon may due to that it maintained the better original structure of the products and the material structure was loose after drying with the method of vacuum freeze dried (T-1) [52]. In addition, the experiments have been supplemented as you suggested about average particle size. The mean particle size of T-1, T-2 and T-3 were $5.864 \mu \mathrm{m}, 10.66 \mu \mathrm{m}$ and $14.21 \mu \mathrm{m}$, and the specific surface area were $30288 \mathrm{~cm}^{2} / \mathrm{mL}, 25224$ 
$\mathrm{cm}^{2} / \mathrm{mL}$ and $19601 \mathrm{~cm}^{2} / \mathrm{mL}$, respectively. However, the rehydration ratio of SDF obtained by hot air drying was less than fifty percentage of that of vacuum dried products. The reason was that hot dried had a high rate of water loss at the initial stage and the structure was seriously damaged.

\section{Conclusion}

In this study, the SDF was purified by enzymatic hydrolysis with papain and glucoamylase after extracted with hot water and precipitated in ethanol from jujube. BBD was adopted to increase the extraction yield of SDF, and the optimal conditions were obtained: extraction temperature of $94^{\circ} \mathrm{C}$, extraction time of $40 \mathrm{~min}$ and ratio of raw material to water of 1:21 $\mathrm{g} / \mathrm{mL}$. It was coincided with the model predictions under these conditions, which the extraction yield of SDF was $20.17 \pm 0.16 \%$. SEM and FT-IR clearly showed that the characteristic structure of SDF has a uronic acid groups. The bioactivity assays indicated that the SDF treated by vacuum freeze dried showed relatively higher antioxidant activity in vitro than that by hot dried.

\section{Acknowledgment}

This work and financial were supported by the Shandong Province Agriculture Major Applied Technology Innovation Project (SD2019ZZ204) and National Natural Science Foundation of China (No. 21705084), and the Natural Science Foundation of Shandong Province of China (No. ZR2017BB074), National Training Program of Innovation and Entrepreneurship for Undergraduates (No. 201710431040), Special Funds for Taishan Scholars Project, and Major Science and Technology Projects in Shandong Province of China (No.2015ZDJQ07003) in Master's Funded project of Jinan University laboratory.

\section{Compliance with ethics guidelines}

The authors declare that they have no conflict of interest. This article does not contain any studies with human or animal subjects performed by any of the authors.

\section{References}

1. Bai, T. C., Wang, T., Chen, Y. Q., Mercatoris, B, Spectrosc Spect Anal, 39, 1323-1328 (2019)

2. Bai, T. C., Zhang, N. N., Chen, Y. Q., Mercatoris, B, Sustainability-Basel, 11, 176-184 (2019)

3. Deng, Q., Deng, Q. X., Wang, Y., Li, L., Long, X. Y., Ren, S., Fan, Y., Lin, L. J., Xia, H., Liang, D., Wang, J., Zhang, H. F., Lv, X. L., Wang, Y. Q, Environ Monit Assess, 191, 1123-1130 (2019)

4. Tang, Y., Xiao, Y., Tang, Z., Jin, W., Wang, Y., Chen, H., Yao, H., Shan, Z., Bu, T., Wang, X, PeerJ, 7, e7149 (2019)
5. Ma, L. H., Wang, X., Gao, Z. Y., Wang, Y. K., Nie, Z. Y.\&Liu, X. L, Agr Water Manage, 216, 436-443 (2019)

6. Qiao, X., Sai, L. H., Chen, X. W., Xue, L. H., Lei, J. J, Plos One, 14, 1435-1445 (2019)

7. Tang, C., Ding, R., Sun, J., Liu, J., Kan, J., Jin, C, Food Funct, 10, 2290-2312 (2019)

8. Sharif, N., Jaskani, M. J., Naqvi, S. A., Awan, F. S, Sci Hortic-Amsterdam, 249, 228-239 (2019)

9. Xu, X. X., Bao, Y. J., Wu, B. B., Lao, F., Hu, X. S.\&Wu, J. H, Food Chem, 289, 250-258 (2019)

10. Zhang, W., Wang, B. J., Gan, Y. W., Duan, Z. P., Hao, X. D., Xu, W. L., Li, L. H, Agroforest Syst, 93, 653664 (2019)

11. Zhang, W., Wang, B. J., Gan, Y. W., Duan, Z. P., Hao, X. D., Xu, W. L., Li, L. H, Agroforest Syst, 93, 591605 (2019)

12. Yan, X. G., Ye, R., Chen, Y, Food Chem, 180, 106115 (2015)

13. Li, X. L., He, X. L., Lv, Y. P.\&He, Q, J Food Process Eng, 37, 293-298 (2014)

14. Perez-Lopez, E., Mateos-Aparicio, I., Ruperez, P, Innov Food Sci Emerg, 38, 76-82 (2016)

15. Wang, T. L., Liang, X. H., Ran, J. J., Sun, J. L., Jiao, Z. G., Mo, H. Z, Int J Food Sci Tech, 52, 741-747 (2017)

16. Wu, D. L., Xu, X. X., Chen, Y. L., Shao, H., Sokolowski, E., Mi, G. H, Agr Water Manage, 213, 200-211 (2019)

17. Nino-Medina, G., Muy-Rangel, D., de la Garza, A. L., Rubio-Carrasco, W., Perez-Meza, B., Araujo-Chapa, A. P., Gutierrez-Alvarez, K. A., Urias-Orona, V, Molecules, 24, 765-773 (2019)

18. Navarro, D. M. D. L., Bruininx, E. M. A. M., de Jong, L., Stein, H. H, J Anim Sci, 96, 2265-2277 (2018)

19. Chandoura, H., Morales, P., Barreira, J. C. M., Barros, L., Fernandez-Ruiz, V., Ferreira, I. C. F. R., Achour, L, Lwt-Food Sci Technol, 64, 446-451 (2015)

20. Ma, M. M.\&Mu, T. H, Carbohyd Polym, 136, 87-94 (2016)

21. Liu, C., Lin, X. L., Wan, Z. L., Zou, Y., Cheng, F. F.\&Yang, X. Q, Food Funct, 7, 4830-4840 (2016)

22. Arun, K. B., Thomas, S., Reshmitha, T. R., Akhil, G. C., Nisha, P, J Funct Foods, 31, 198-207 (2017)

23. Dos Reis, L. C. R., Facco, E. M. P., Salvador, M., Flres, S. H., de Oliveira Rios, A, Journal of Food Science \& Technology, 23, 276-285 (2018)

24. Ge, Q., Mao, J. W., Cai, C. G., Huang, J., Zhou, Y. F., Fang, J. L., Sun, Y. X., Sha, R. Y, J Biobased Mater Bio, 11, 385-390 (2017)

25. Huang, L. R., Zhang, W. X., Cheng, J., Lu, Z. B, Int J Food Prop, 22, 678-688 (2019)

26. Wu, D. T., Liu, W., Han, Q. H., Du, G., Li, H. Y., Yuan, Q., Fu, Y., Zhao, L., Zhang, Q., Li, S. Q., Qin, Int J Biol Macromol, 136, 891-900 (2019) 
27. Esmaeili, M., Mohammadi, A, Wireless Pers Commun, 94, 2797-2818 (2017)

28. Qiu, S., Yadav, M. P., Yin, L. J, Food Chem, 230, 225-233 (2017)

29. Chen, Y. M., Lim, C. J., Grace, J. R., Zhang, J. Y., Zhao, Y. C., Zheng, C. G, Chem Eng Sci, 129, 156167 (2015)

30. Ozyurt, V. Y. H., Ötles, S, Acta Sci Pol Technol Aliment, 15, 233-245 (2016)

31. Jain, A., Grewal, R. B, Food Chem, 204, 225-233 (2015)

32. Jia, M., Chen, J., Liu, X., Xie, M., Nie, S., Chen, Y., Xie, J., Yu, Q, Food Hydrocolloids, 187, 769-778 (2019)

33. Lorenz, P., Berger, M., Bertrams, J., Wende, K., Wenzel, K., Lindequist, U., Meyer, U., Stintzing, F. C, Anal Bioanal Chem, 391, 633-646 (2008)

34. Jiang, Y. Y., Wang, L., Zhang, L., Wang, T., Yu, L., Ding, C. B., Yang, R. W., Wang, X. L., Zhou, Y. H, Int J Biol Macromol, 70, 92-99 (2014)

35. Zhao, Y. M., Song, J. H., Wang, J., Yang, J. M., Wang, Z. B., Liu, Y. H, J Sci Food Agric, 96, 44844491 (2016)

36. Zhao, T., Mao, G., Feng, W., Mao, R., Gu, X., Li, T., Li, Q., Bao, Y., Yang, L., Wu, X, Carbohydr Polym, 105, 26-33 (2014)

37. Chen, B. F., Cai, Y. J., Liu, T. X., Huang, L. H., Deng, X. L., Zhao, Q. Z., Zhao, M. M, Food Hydrocolloid, 93, 167-175 (2019)

38. Jia, M. Y., Chen, J. J., Liu, X. Z., Xie, M. Y., Nie, S. P., Chen, Y., Xie, J. H., Yu, Q, Food Hydrocolloid, 94, 468-474 (2019)

39. Xie, J., Li, K. Z., Sun, G. D., Li, H., Su, X. H., Han, Y. S., Li, T, Ceram Int, 45, 11912-11919 (2019)

40. Sun, B. F., Yuan, Y. N., Li, H. L., Li, X. Y., Zhang, C. H., Guo, F., Liu, X. H., Wang, K. A., Zhao, X. S, Chem Eng J, 371, 55-63 (2019)

41. Skotnicka, M., Ocieczek, A., Malgorzewicz, S, Int J Food Prop, 21, 1138-1151 (2018)

42. Pellegrini, M., Lucas-Gonzales, R., Ricci, A., Fontecha, J., Fernandez-Lopez, J., Perez-Alvarez, J. A., Viuda-Martos, M, Ind Crop Prod, 111, 38-46 (2018)

43. Xie, F., Zhang, W., Lan, X. H., Gong, S. X., Wu, J. H., Wang, Z. W, Int J Food Prop, 20, S2939-S2949 (2018)

44. Du, X. J., Bai, X. P., Gao, W., Jiang, Z. F, Int J Food Sci Tech, 54, 1390-1404 (2019)

45. Lin, Y. A., Wang, H. X., Rao, W., Cui, Y. W., Dai, Z. Y., Shen, Q, Food Control, 98, 74-81 (2019)

46. Shang, W. H., Tang, Y., Su, S. Y., Han, J. R., Yan, J. N., Wu, H. T., Zhu, B. W, Food Funct, 9, 6436-6444 (2018)

47. Wang, C. H., Ni, Z. J., Ma, Y. L., Thakur, K., Zhang, J. G., Prasad, C., Wei, Z. J, Curr Top Nutraceut R, 17, 195-205 (2019)
48. Tapia-Salazar, M., Arevalo-Rivera, I. G., Maldonado-Muniz, M., Garcia-Amezquita, L. E., Nieto-Lopez, M. G., Ricque-Marie, D., Cruz-Suarez, L. E., Welti-Chanes, J, Food Bioprocess Tech, 12, 512-523 (2019)

49. Navarro-Gonzalez, I., Garcia-Valverde, V., GarciaAlonso, J., Periago, M. J, Food Res Int, 44, 15281535 (2011)

50. Lee, K. Y., Park, K. H., Lee, H. G, Food Sci Biotechnol, 25, 477-482 (2016)

51. Wu, Z. Y., Lin, W. X., Li, B. L., Wu, L. K., Fang, C. X., Zhang, Z. X, Plos One, 10, e0129397 (2015)

52. Sui, W. J., Xie, X., Liu, R., Wu, T., Zhang, M, Food Hydrocolloid, 84, 571-580 (2018) 